\title{
Efforts and changes around school libraries in Sweden today - Whats new after Long Beach?
}

\section{Fredrik Ernerot}

\author{
School Library West, Gothenburg, Sweden
}

As the 2017 IASL conference theme in Long Beach, California was "Learning without borders" its interesting, almost one year later, to focus on how the school library, as well as the school librarian, will have to adopt the field - to establish and develop the field as a whole.

By describing the whole field, with a perspective taken from the Swedish school library, from the present situation 2017/2018 and even further than that, there will be a contribution of useful material and methods - inspirational to the work and progress for school libraries/school librarians, both on a national and international level.

This time one specific subject will be presented during the lecture - mainly to create a sustainable knowledge for school libraries - with a special focus on the political and structural efforts and changes taking place in Sweden today.

\section{OBJECTIVES OF THE PRESENTATION}

The following subjects are set to be the platform, focusing on the session:

Efforts and changes around school libraries in Sweden today - Whats new after Long Beach?

The Swedish National agency of education - The school law, as well as new statistics on the situation for school libraries. More over exclusive information on the political and structural efforts around school libraries in Sweden today.

The topics are:

1. A presentation of the work inside the reference group during 2017/2018, where meetings, conferences and discussions between the Agency, teachers and librarians, have been implemented. 
2. Governmental economical investment on staff for Sweden's wide scale of municipalities.

3. The cooperation around the school library issue between eight national agencies.

4. An updated curriculum for the elementary school, where special demands for principals around the use of school libraries are included, as well as the digitization of the elementary school.

\section{Clear description of what participants will learn:}

The ambition is to give participants in Istanbul, both national and international guests, thoughts on how changes around school libraries can be done in a practical way - both on a governmental and a collegiate level.

- Learn how to communicate on each specific level, as well as between different levels.

- Learn how to create a reference group, where discussions leads to knowledge and even more important - how the knowledge can help building platforms for decision makers.

Decisions that in the end can be included in such foundations as curriculums and admitted plans for national digitization. Then, if participants in Istanbul want to embrace some of the thoughts directly during the conference - there will for sure be even more to learn.

\section{INTRODUCTION}

Sweden (9,9 million people) has 290 municipalities, 290 public library systems, and about 4000 school libraries. Public libraries and school libraries are financed by local authorities. The municipal council makes decisions in matters concerning libraries, compulsory school, upper secondary school and preschool. Sweden has a long tradition of local municipal autonomy. Local authorities are independent bodies, which are free to make their own decisions within certain limits. Compulsory schooling in Sweden is from first to ninth grade. A preschool year from six years of age is a part of Swedish schools, but not compulsory for children. 
"When local authorities are given new tasks, their right to municipal autonomy must be taken into account. This sort of situation may arise when an area in which local authorities have previously provided services on a voluntary basis, such as libraries, is brought under regulation", the government says. This is why legislation often is not detailed. School directors and principals are the ones who have mandate from the local authorities to decide how the money is spent and how the schools are going to follow the law. The Swedish schools, principals and municipalities must now manage school libraries.

The National Library of Sweden (KB) has the responsibility to coordinate support for all libraries. Within the public library sector, there are 20 county and regional libraries with the assignment to encourage cooperation and development through projects such as reading promotion, development of library service for different target groups, and lifelong learning. According to the Library Act, regional libraries do not have mandate to provide for school libraries, but they can cooperate with school libraries in their regions.

\section{THE SWEDISH NATIONAL AGENCY FOR EDUCATION}

\section{A summary and a definition of the school library:}

The Swedish National Agency for Education has a valuable department working with school library issues. The Agency has a reference group for school library matters. An Agency officer manages a discussion list for school librarians, provides informative journalistic web articles on school library best practice, and a website called Check the source about information literacy, critical awareness, use of social media and web tools for daily school work (a website that will change form in the summer of 2018). In the guidelines from the National Schools Inspectorate, a definition of school library from the Agency is quoted:

A shared and well-regulated resource comprised of media and information, which is put at the disposal of the pupils and teachers with the help of competent staff. The school library is a part 
of the school's teaching activities with the task of supporting the pupils' learning. The school library can therefore be regarded partly as a material resource which is part of a school's teaching aids and other tools, and partly as a function which actively contributes to the development of knowledge and is responsible for certain services. (Translated in Jensinger, 2013)

\section{Background:}

The Swedish National Agency for Education is one of the three big national authorities for schools, belonging to the Ministry of Education and Research. The other two governmental authorities are The Schools Inspectorate and The National Agency for Special Needs Education and Schools.

\section{The Swedish education system 1:}

In Sweden there are almost 11000 schools (pre schools included). 1, 5 million pupils (21\% of the population). There are about 4000 school libraries connected to compulsory and upper secondary schools (6078 school). According to statistics from $201067 \%$ of the Swedish schools units have a school library. One third of the Swedish pupils have no access to a school library. Statistics 2016 and 2017 shows similar figures as mentioned above.

\section{The Swedish education system 2:}

The Swedish school system is decentralized since 1991, which means that the municipalities/local schools authorities are responsible for and finance the schools, even the independent schools.

Independent schools: $9 \%$ of the pupils in compulsory and $17 \%$ in upper secondary school.

The national goals for Swedish schools are set by: The Swedish Parliament and Government in The Education Act, Curricula, Course Syllabi and Program Goals. All these documents (apart from the Education Act) has been renewed and revised in 2017.

To put some weight behind the words here, the Swedish minister of schools Jan Björklund quoted: The Swedish School System is "undergoing the biggest school reform since 1842". 


\section{The new Education Act:}

A proposition about a new Education Act was left for political decision in 2010.

It was approved. The start was set to autumn 2011.

One important reform within the Education Act is that Swedish pupils are guaranteed access to school libraries. This does not mean that every rural school with 50 pupils have to employ a librarian, but as school authority you have to include school library - the pupils need for information and reading possibilities in your plan for school activities.

Being part of the Education Act also means that the school libraries are included in the inspection of schools (made every third year by The Schools Inspectorate), something that has not been reality earlier.

\section{The National Agency and school libraries:}

The goal for the Agency is to steer and support schools through different steering documents. The Agency was head of big national school library projects during the years 2000-2004 as well as 2007, including competence development for school librarians.

The Agency also publishes research about school library and information literacy, as well as school library articles on the Agency's website.

There is also a discussion list for school librarians with around 1000 subscribers, as well as wikis for teachers and librarians.

The reference group for school libraries at the Agency started 2009. There were discussions about strategic issues and even printed/digital materials were produced through the group. 
Later on the group focused on a referral for the new Education Act, as well as the definition on school library (referred earlier in the text).

Part of the paper and lecture at IASL Long Beach, CA, august 2017 - News from the Swedish National Agency for Education:

- With a start in autumn 2016 principals have the possibility to search for contribution, when it comes to reinforce staff at the school library. The Agency administrates the governmental funding for school librarians. 1, 6 million dollars in 2016. 3, 2 million dollars in 2017. An evaluation will take place 2017 (note: the result of the evaluation is now published, April 2018).

- All Swedish curriculars are being revised during 2017 with the aim to strengthen the writings about digital competence. The schools can decide to start working with the revised versions from July 1, 2017 (note: the curriculum, as well as extra material about the digitization of the elementary school, is ready for use summer 2018).

- School library in the revised curricula: It's the principles responsibility that the school library is being used to support teaching, empower the pupil's language abilities and their digital competence (note: the sentence is ready for use summer 2018). This is an important sentence and a tool and argument for staffing the school library with an educated school librarian.

- The Agency also offers training initiative, where school librarians are a special target group. A reading- as well as a media literacy staking will be offered for both school librarians and teachers (note: set and running since the autumn 2017).

- A new reference group of school librarians (40-50 members) is formed. As an effect of that a wide scale of conferences, meetings and projects are organized. Everything is connected to the above skills development (note: the last conference where organized in Gothenburg, April 2018).

- Since 2016 The National Agency for Education is member of a network consisting of eight national authorities, three of them school authorities. The main issue for the group is school libraries. The group supports the work with the national library strategy with some external environment monitoring. For example: In 2016 the network published an overview about 
Swedish school libraries. There is also a discussion about producing a leaflet addressing school providers (note: One out of four suggestions that the National Agency for Education has reported to the Government during spring 2018).

- There will be a new strategy set for the Swedish Library ready in 2019 . The school library will be a main field for the work with the strategy.

\section{THE POLITICAL AND STRUCTURAL EFFORTS AROUND SCHOOL LIBRARIES IN SWEDEN TODAY}

About four years ago, during the yearly Book fair in Gothenburg, an important conversation took place during a dinner meeting. Specially invited, due to a guest lecture at the Book fair, was $\mathrm{PhD}$ Ross Todd, Rutgers University, New Jersey, USA. The association behind the invitation was School Library West. The regional association connected to the National School Library Group. The reason for the invitation was to discuss how to progress on a national basis when it comes to school library development. Mr. Ross Todd is one of the most central and important educators around school libraries in Sweden. He has during a long period put a lot of time and effort on the field, and there for owns a lot of knowledge about especially the structural efforts around school libraries in Sweden.

As new Education Act in Sweden was published in 2011, a first solid ground made for further steps already existed. The meeting mainly focused on questions related to the next step, set by Ross Todd himself. For example:

- Which stakeholders can be of use for further progress in Sweden?

- How can they put pressure on the Swedish Government?

- To set the next agenda for school libraries, how can you manage to do that? 
What is so interesting to see today is: how many loose bricks in the wall, at the time for the meeting, that now fits perfectly into the great wall of school libraries in Sweden today.

The pressure put on the Government came through, and even if it wasn't caused but the meeting with Ross Todd, the right intentions, thoughts and suggestions were there to see.

The agenda shaped by several different steps/tools shown in the paper, presented at IASL conference 2017 in Long Beach, California, summon the complete period well. The most important steps/tools are also included in this paper, about one year further down the road.

The news section presented before shows how many things that take place in Sweden today. One explanation why there are so many things happening right now is: political efforts. Since last election in Sweden (2014) the Minister of Education Gustav Fridolin (Left wing) has been very positive about school libraries, He has seen great importance in using libraries, as well as putting effort in the question: How to get more staff to run the libraries. The economical funding - to give Swedish schools the possibility to search for contribution, when it comes to reinforce staff at the school library, is one of the things the Minister of Education has been a part of right from the start.

Apart from the support on an economical level, there have been other types of support acts taking place during the same period. The network consisting of eight national authorities is another thing. The group supports the work with the national library strategy, with some external environment monitoring, something that is rather unique even on a global level. The interesting thing to witness right now, achieving reports from the group, and listening to different lectures, is that the most topics handled by the group's national authorities shows what a "real group" it has become.

- There are really not any differences between us. When it comes to important issues like: the role for the school principal, getting staff to the libraries and encourage co-operation between librarians and teachers, we have the same view on it. / The Swedish School Inspectorate, part of a conference in Gothenburg, April 2018, arranged by the National Agency for Education. 
When it comes to the new curriculum for the school in Sweden there is one point (2.8) that specializes on the responsibility for principals: School library in the revised curricula.

- It's the principles responsibility that the school library is being used to support teaching, empower the pupils' language abilities and their digital competence.

This is an important sentence and a tool and argument for providing the school library with an educated school librarian. Principals around the country is now preparing for this new sentence. A sentence that demands both action and knowledge around a field which many schools don't even own today. There is a bit of stress at the moment. But, this is not the only thing coming up...

There is more pressure put on the topic. That is caused by the following reason:

In 2017 The Swedish Department of Education ordered a national investigation on the situation for school libraries today. And the address for the order: The National Agency for Education. In March 2018 the report was ready for deliverance. Both a full report and a Memo were published. The attention shown to the publications was huge!

Here follows a selected part of both publications, directly translated from Swedish.

1. THE SWEDISH NATIONAL AGENCY FOR EDUCATION:

MEMO - THE ROLE OF SCHOOL LIBRARIES NEEDS TO BE

STRENGHTENED, MARCH 2018.

The school library's educational function is not enrolled in the school law. Therefore, the National Agency for Education proposes that the government investigate whether the 
school law can clarify the role of school libraries in school. School libraries should be an integral part of the teaching and the school libraries skills need to be taken care of.

- At a time when students face propaganda and "fake news" in social media, school libraries knowledge about source criticism and media is more important than ever. School libraries can also help increase student readings, but its potential is not fully utilized today, says Anette Holmqvist, Education Advisory Board at the National Agency for Education.

In the report that the National Agency for Education has now submitted to the government, teachers and principals have little knowledge of the purpose and role of school libraries. It can explain that co-operation between teachers, principals and school libraries is often weak. The availability of school libraries is not equivalent today. According to the Royal Library's statistics, only half of the country's 1.3 million students have access to a school library with about half time crew.

- It is important that it becomes clear that a school library is not just a shelf with books. The curricula contain new writing on the function of school libraries, but we believe that it needs clarification in the school law, "says Anette Holmqvist.

There is a lack of educated school librarians. It is difficult for schools to offer high quality activities and is a contributing factor to the availability of school libraries. The fact that there is a lot of differences between schools is a problem, but there are also big differences in how school libraries are used.

- To meet the curriculum requirements, school libraries need to be an integral part of the teaching. It is an activity that needs to be planned and evaluated to best contribute to the learning of all students, says Anette Holmqvist.

To strengthen knowledge about the role of school libraries, The National Agency of Education will evolve more skills development within the framework of the National School Development 
Programs. The National Agency for Education will also provide support to assist principals and teachers to interpret and follow the curricula's new writing on school libraries. The National Agency for Education also allocates government grants for staff reinforcements in school libraries.

2. THE SWEDISH NATIONAL AGENCY FOR EDUCATION:

REPORTING OF GOVERNMENT ASSIGNMENTS, MARCH 2018.

Reporting of assignments to review to what extent the school library function and school libraries skills today is best used to strengthen the education quality.

\section{The assignment}

Hereby the task is to review the extent to which the school library's function and

The school libraries skills today are best used to strengthen the education quality.

The National Agency for Education shall, if necessary, submit proposals for measures, constitutional amendments and, if appropriate, propose financing.

\section{Summary}

The regulation letter for the financial year 2017 indicates that the National Agency for Education should review to what extent the school libraries function and the skills of the school libraries are used today, best way to strengthen the quality of education.

The National Agency for Education shall, if necessary, submit proposals for actions, constitutional amendments and, if appropriate, proposing funding.

The National Agency for Education has carried out the assignment in two main steps: 
A compilation which describes current research and previous studies on school libraries and consultation with relevant actors internally at the National Agency for Education, government representatives, representatives for principals as well as with associations.

Based on the current state of knowledge and in the consultation, presents a number of possible measures.

The following four measures are the most central ones according to the situation for school libraries in Sweden today:

\section{The government can investigate if the school law can be clarified}

The school libraries educational function is not regulated in the school law. It only indicates that pupils should have access to school libraries. If school libraries in the best way should be used to strengthen the quality of education, it is important to clarify the schooling that they are an integral part of the teaching.

\section{The National Agency for Education should offer efforts to strengthen school library activities} within the national school development programs

Knowledge and awareness about the purpose and role of school libraries and school libraries skills are low among teachers and school leaders. There is also a need for increased skills of educated school libraries for the best possible use, contribute to the schools goal fulfilling work. The National Agency for Education offers competence development efforts within the framework of the national school development programs. School libraries are already a target group for the efforts "Reading Boost" and "Digital competence", but should be given the opportunity to participate in several of the national school development programs. In order to meet these needs, the Swedish Agency for Education offer more efforts to strengthen school library activities within the framework of the national school development programs. The target groups for the efforts should be school libraries, school leaders, teachers and principals. 


\section{The National Agency for Education can provide support material on school library activities}

In March 2017, the government decided on clarifications and reinforcements in curricula, that clarify that the school library should be used as part of the teaching. The National Agency for Education believes that it is important that principals and school leaders receive the support they need to be able to interpret these new writings and take the required responsibility.

The National Agency for Education can therefore provide support materials for principals and school leaders and develop the existing material for teachers and school libraries. Purpose of the support material is that all target groups can act better in order to live up to the requirements of the curriculum, by consistently including school library activities in its systematic quality work.

4. The state contribution to school libraries should be part of the new state grant for strengthened equivalence and knowledge development

Today, digital solutions, media and premises for school library operations are often lacking. In addition, only half of the country's 1.3 million students have access to a school library with about half time crew. There is a need for a long term funding for school library activities.

At the same time, both the Swedish National Agency for Education and other actors identified problems with the many state grants in the field of education. The National Agency for Education therefore proposes that the funds, for which is today calculated as Government grants to school libraries, are brought to the new contribution for strengthened equivalence and knowledge.

\section{AN UPDATED CURRICULA FOR THE ELEMENTARY SCHOOL}

The National Agency for Education also takes the opportunity to comment on the new curriculum for Sweden's elementary school. A few amendments are added as well: 


\section{The new curricula}

In the recently revised curricula for elementary school, foundation school, joint school, special school and upper secondary and secondary school, the government has clarified the principles responsibility for the school library's activities. The curricula mention, "school library activities should be used as part of the teaching to strengthen the student's linguistic ability and digital skills ".

\section{School Inspectorate's position}

The School Inspectorate specify in a statement about school libraries that the following requirements shall apply be met, to ensure that students in municipal and independent schools are considered to have access to a school library:

"Students have access to a school library at their own school premises or on reasonable distance from the school that makes it possible to use the library continuously as part of student education, to help achieve the goals for this. The library includes books, fiction and information technology and other media. The library is adapted to students' needs to promote language development and stimulate reading. "

\section{School library within the national digitization strategy}

Within the governments national digitization strategy for the Swedish school system states that "in order for children and students to develop as far as possible, it is also of emphasis on good cooperation between staff working with children and students and school libraries. The school library has an important educational task to fill when it is intended to strengthen students skills in, among other things, information retrieval and source criticism ". 


\title{
THE REFERENCE GROUP FOR SCHOOL LIBRARIES - AN EFFECTIVE TOOL USED BY THE NATIONAL AGENCY FOR EDUCATION
}

\begin{abstract}
A presentation of the work inside the reference group during 2017/2018, where meetings, conferences and discussions between the Agency, teachers and librarians, have been implemented.
\end{abstract}

The National Agency for Education started the reference group for school libraries in 2009. At start there were discussions about strategic issues. Printed/digital materials were also produced through the group. Later, the group started to focus on a referral for the new Education Act, as well as a definition on what a school library is. Some parts of the definition mentioned in the Education Act are taken from the suggestion headed over by the reference group.

\section{Meetings}

There were more meetings arranged for the group in the early years of its existence. But, back then there were exclusively school librarians called for meetings, and almost no conferences were arranged by the Agency. The last two years it has shifted rapidly. Today there are relatively few meetings, but when they take place it's with a great variety of participants - such as librarians, teachers and responsible persons for digital development. Shifted meetings, where different professions get together around relevant issues, have been of great use - both for the Agency and the participants part of the reference group.

\section{Conferences}

The main activity for the reference group today is being an active part of the conferences arranged by the Agency. One conference in every six months is offered broadly. They are spread out all over the nation. The model for each conference is: An informative content with several 
lectures and workshops around a current topic, as well as interactive elements where participants at the conference are held around certain topics, managed practically by the members of the reference group. One main purpose is to get active and reflective discussions out of the group, as important knowledge for the contenders' development inside their own profession. Another purpose is to hand over information directly to the Agency.

Digital applications and programs are used for documentation, where contenders either contribute all together, or simply by purchasing answers on each contender's digital tool. Much of the information collected by the Agency is used for developing relevant support platforms, as well as new discussions and new printed material.

\section{Sounding board}

Being the first ones to know. Being the first ones to get questions around new things coming up. Being the first ones to test new material. Being the first ones to get response around the field. Being the first ones...

To communicate, listen carefully and exchange knowledge with each other - Both between the Agency and the members in the group, and between members inside the group, is extremely important. This is the best education a single school librarian or teacher possible can get.

\section{FINAL WORDS}

The exchange and co-operation between stakeholders on a government level and the librarians and teachers part of everyday life in school, is a considerable amount of the outcome concerning this paper. With out this exchange almost nothing in this report would have been written and published. There for I hope this model will inspire and encourage you.

Bring it home to your own country. Make up a plan - how to put pressure on the Stakeholders, just like PhD Ross Todd did, a few years back, joining in on a plain dinner meeting in Gothenburg, Sweden. 


\section{REFERENCES}

Barrett, Helle, \& Eriksson, Bibbi. (2013). A government mandate for school libraries in Sweden, from http://www.ifla.org/node/7926

Holmqvist, Anette. (2010). Today and tomorrow - The Swedish school libraries in a national perspective and context. Available as PDF/Power-point presentation, from http://www.skolverket.se

Jensinger, Edward. (2014). Headmaster's view of the school library. Scandinavian Library Quarterly, 46 (1), from http://slq.nu/?article=volume-46-no-1-2013-7

The Swedish Government. (2017). U2017/04119/S, National digitalization strategy for the school system

The National Agency for Education. (2018). Memo. The role of school libraries needs to be strengthened https://www.skolverket.se/omskolverket/press/pressmeddelanden/2018/skolbibliotekens-roll-behover-starkas-1.268292

The National Agency for Education. (2018). Reporting of government assignments, https://www.skolverket.se/om-skolverket/publikationer/visa-enskildpublikation? xurl =http $\% 3 \mathrm{~A} \% 2 \mathrm{~F} \% 2 \mathrm{Fwww}$.skolverket.se $\% 2 \mathrm{Fwtpub} \% 2 \mathrm{Fws} \% 2 \mathrm{Fskolbo}$ k\%2Fwpubext\%2Ftrycksak\%2FBlob\%2Fpdf3937.pdf\%3Fk\%3D3937

The School Inspectorate. (2018b). School library

https://www.skolinspektionen.se/sv/Rad-och-vagledning/Stallningstaganden/skolbibliotek/

International Association of School Librarianship https://www.iasl-online.org/ 